\title{
Analysis of financial contagion in influential African stock markets
}

\author{
Oluwatosin Mary Aderajo ${ }^{1}$ and Oladotun Daniel Olaniran ${ }^{2^{*}}$ (D)
}

\begin{abstract}
Drawing from the experience of the global financial crisis that sprang forth from the US stock market, an empirical assessment of the dynamic correlation analysis of financial contagion with evidence from (5) African countries (South African, Nigeria, Egypt, Kenya, Tunisia) is presented. Monthly stock prices indices from 2004 to 2018 was analyzed using the dynamic conditional correlation multivariate GARCH model to ascertain the contagious effect of the US to the selected African markets. By analyzing the correlation coefficient series, three phases of the crisis periods were identified \{pre-crisis (2004-2007); crisis (2007-2009) and post-crisis (2009-2018), respectively\}. The study revealed that a significant relationship exists between the returns of the US market and the African markets. The inspection of the pre-crisis, crisis, post-crisis mean and variance estimation shows that the crisis period is characterized by substantial increases in volatility, establishing that the shock experienced in the US posed a threat to the African markets being examined. Further, evidence revealed that in the crisis period, an increase in correlation (contagion) existed, while a continued correlation (herding) existed in the post-crisis period.
\end{abstract}

Keywords: Financial contagion, Herding, GARCH, Correlation, Global financial crisis, Stock market

\section{Introduction}

Essentially, the world is becoming more and more globalized, such that it has become practically impossible for countries to operate in isolation. A self-sufficient economy based on autarky has been replaced with interaction in virtually all countries of the world, and in this circumstance, the intermediary role played by financial markets have resulted in the increased need for financial integration, which allows capital to travel to its most attractive destination [6, 21]. Integrated financial markets facilitate inter-temporal capital flows and portfolio diversification but at the same time may increase the probability of financial crisis and the contagion of crisis across countries. This risks however depends heavily on the degree of financial market integration, i.e., the more the integrated markets are, the higher the contagious effect of a shock from one market to another and conversely, countries

\footnotetext{
*Correspondence: olanirandotun@gmail.com

2 Department of Economics, Obafemi Awolowo University, Ile-Ife, Nigeria

Full list of author information is available at the end of the article
}

that are less integrated should then be relatively immune to contagion (see $[5,11,26]$ ).

Although awareness of financial contagion was raised after the Asian crisis of 1997, shocks were being transmitted internationally long before the Asian crisis. Among this includes crisis that arose from the abandonment of the gold standard in 1993 and the breakdown of the Bretton woods currency regime in 1973. The term financial contagion has widely been used in the empirical literature, stemming from the early works of King and Wadhwani [23] as one of the empirical pioneers. For instance, Forbes and Rigobon [16] defined it as a significant increase in cross market linkages resulting from a shock hitting one country or a group of countries.

Also, Sun and He [30] opined that it is a significant increase in the propagation and penetration of shock across countries. However, for Hughes and MacDonald [18] as well as Tiwari et al. [32], the contagion effect is generated by a financial crisis in one country spreading into the financial system of other countries.
Springer Open

(c) The Author(s) 2021. This article is licensed under a Creative Commons Attribution 4.0 International License, which permits use, sharing adaptation, distribution and reproduction in any medium or format, as long as you give appropriate credit to the original author(s) and the source, provide a link to the Creative Commons licence, and indicate if changes were made. The images or other third party material in this article are included in the article's Creative Commons licence, unless indicated otherwise in a credit line to the material. If material. is not included in the article's Creative Commons licence and your intended use is not permitted by statutory regulation or exceeds the permitted use, you will need to obtain permission directly from the copyright holder. To view a copy of this licence, visit http://creativeco mmons.org/licenses/by/4.0/. 
According to the World Bank Group [34], contagion was given three definitions: the broad, restrictive and very restrictive definition. For the broad definition, contagion is defined as the general process of shock transmissions across countries. The restrictive definition is the most controversial of the three and is defined as the transmission of shocks to other countries or the crosscountry correlation, beyond any fundamental link among the countries and beyond common shocks. In the literature, financial contagion has been linked to factors such as asset market effects as well as banking and currency channels (see [19, 27]).

It has also been linked to fundamental effects such as common shock and trade effects (see [4, 13]), investor behavior related effects (see $[9,12])$ and issues relating to liquidity problem and information asymmetries [14, 22]. Economists believe that every time a developed country sneezes, the rest of the world's developing and emerging markets are likely to suffer from it by catching a flu to a large extent, no matter how good their fiscal accounts are or how balance their external account is $[10,15]$.

Financial contagion has been viewed in the literature as mainly a concern for emerging markets. However, the global financial crisis of 2007 confirmed that financial crisis is not limited to certain groups of markets such as developed or emerging markets, because it is assumed that rescue plans are already put in place to insulate many developed countries during the 2007 financial crisis. Interestingly, the situation actually differs for African markets as no African country announced a bank rescue plan as observed in many developed countries [1]. Africa being a developing region has not been an exemption to the movement toward full financial integration being experienced across the world. However, in spite of several financial reforms being undertaken to promote financial integration in Africa, her macroeconomic fundamentals remain weak and the process of financial integration is relatively slow as compared to that of emerging countries in Asia and Europe [20, 28].

Since financial integration acts as a double-edged sword which can foster financial stability and as well instigate a financial crisis through financial contagion, two (2) question which readily comes to mind are: To what extent has the US financial market affected African markets and Does Africa have the capacity to pull through a contagion risk in the case of an extreme shock? In order to answer these questions, this study as a departure from previous studies will examine the relationship between the returns of the specified African markets and the US and investigate the vulnerability of financial contagion and herding in the specified African markets before, during and after the episode of the 2007-2008 financial crises. Also, as a pioneer in this research area, will focus on five (5) major influential economies in Africa, namely South Africa, Nigeria, Egypt, Kenya, Tunisia, as these countries arguably have the strongest financial markets in Africa and are also the top foreign direct investment (FDI) destinations in Africa.

The remainder of the paper is presented as follows: section two discusses the review of relevant literature, section three focuses on data, while sections four and five are on methodology, discussion of results, and conclusion, respectively.

\section{Review of the literature}

The literature on financial contagion is extensive across various regions. This link has been explored for advanced markets (see [12, 17, 22-24, 29, 32]), for Asian markets (see $[2,6-8,30,33])$ and African markets (see $[3,5,26$, 27]).

Among the existing studies above, a number of empirical studies have revealed the existence of contagion in advanced markets. For instance, King and Wadhwani [23] tested for contagion in the stock markets of New York, London and Japan during the 1987 US market crash. Based on correlation coefficient, the analysis suggests that cross-market correlations increased significantly during the crisis.

Similarly, Masih and Masih [24] tested the relationship among six stock markets of developed nations (US, Japan, France, Canada, Germany and UK), before and after the stock market crash of 1987. It was found that the crash brought about a greater interaction among markets and evidence of a single co-integration vector over each of the pre-crash and post-crash samples.

Also, Missio and Watzka [25] examined financial contagion in a sample of seven (7) countries, namely Germany, Greece, Portugal, Spain, Italy, Netherlands, Belgium and Austria, between 2008 and 2010. The results indicated that there was occurrence of contagion in Portugal, Spain, Italy and Belgium.

In the same vein, Syllignakis and Kourectas [31] studied the emerging stock markets of Central and Eastern Europe for the period of 2007-2009, the results indicated that the emerging markets were exposed to external shocks with a substantial regime shift in conditional correlations.

Also, Corbet and Twoney [12] reveal the evidence of contagion mechanics attributed to herding behavior in European markets between 2007 and 2013 to the G7 countries' market examined.

Tiwari et al. [32] found a short run correlation during the period of financial distress and co-movement among markets in the long run. However, Karanasos et al. [22] reported time-varying correlation and 
volatility spillover effects between the returns of markets examined.

In the case of emerging markets, Arestis et al. [2] tested for contagion in the four largest emerging markets of Asia, namely Thailand, Indonesia, Korea and Malaysia, against a set of developed markets, namely Japan, the UK, Germany and France (major lenders) during the 1997 East Asian crisis. Evidence of contagion was found between the major lenders to the emerging markets. This was attributed to the reduction in bank lending from the major international lenders.

Wang and Thi [33] examined the impact of Asian financial crisis on Chinese Economic Area (CEA) between 1992 and 2002. Conditional correlation coefficients were found positive, and co-movement existed among the Thailand and CEA markets. For all the markets, the variances were higher in the post-crisis period than in the pre-crisis period, indicating an evidence of contagion. Similarly, Chiang et al. [8] reveal the evidence of contagion effect from the Asian crisis of 1997 in Thailand, Malaysia, Indonesia, Philippines, South Korea, Taiwan, Hong Kong and Singapore from 1990 to 2003.The first phase of the crisis displaying a process of increasing correlations (contagion), while in the second phase investor behavior converged and correlations were significantly high (herding behavior) across the Asian countries.

In Africa, Collins and Biekpe [11] examined the existence of contagion between African equity markets and global emerging equity markets during the Asian crisis of 1997. Evidence was found that the larger and more integrated markets in Africa (Egypt and South Africa) suffered from contagion during the Hong Kong crisis of 1997.

Morales and O'callaghan [26] reports no evidence of contagion in 58 countries between 2003 and 2009. It was revealed that markets suffered mostly from spill over effects originating from the US.

Meanwhile, Bouri [5] reports a sudden increase in conditional volatilities during financial crisis and a dynamic conditional correlation of equity markets returns of 12 equity markets in MENA between 2005 and 2013.

Boako and Alagidede [4] examined the evidence of shift-contagion in African stock markets using conditional value at risk (CoVar) between 2003 and 2016. The study found that global shock propagation to developing markets stagger during the global financial crisis of 2007 but becomes more pronounced after the crisis.

Offiong et al. [27] examined financial contagion and its impact on the Nigerian stock market using the Bayesian VAR model in periods before, during and after the global financial crisis. The findings showed that that American and Chinese market negatively affected the Nigerian stock markets, with a pronounced effect as a result of the fall of the naira exchange rate.

Thus, the review of literature shows that studies exist on stock market linkages and financial contagion. Given the various methodologies and the different time frame adopted, these studies have largely reported inconsistent results. Only few of these studies reported can be linked to Africa as most of them have concentrated on Europe and Asian countries. This therefore calls for further investigation on the dynamic analysis of financial contagion in African stock markets.

\section{Data}

For this research, we consider monthly stock prices indices from January 2004 to July 2018. The sample countries include those which have relatively strong financial markets in Africa. Additionally, the sample captures the selected countries' yields vis-à-vis the US because the financial crisis originated from the US The analysis is done at three levels; pre-crisis (2004-2007), crisis (20072009) and post crisis (2009-2017). The stock indices of the selected African countries are depicted as follows: South Africa (JSE), Egypt (EGX), Nigeria (NSE), Kenya (KSE), Tunisia (TSE), and obtained from "investing. com." The starting date of January 2004 is considered as the beginning of the stable period, prior to the period of financial crisis. The ending date of the turmoil period is assumed to be 2009 .

\section{Methodology}

The model for estimating DCC is a dynamic specification based on conditional correlations within GARCH. The DCC-GARCH model is chosen over other estimation techniques because it takes into account drawbacks of other estimation methods, by accounting for heteroscedasticity directly via the estimation of correlation coefficients of the standardized residuals. It can also be used to examine multiple asset returns without adding too many parameters. Following Chiang et al. [8], a standard GARCH model is employed such that:

$$
\varepsilon_{t}=D_{t} v_{t} \sim N\left(0, H_{t}\right)
$$

where $\varepsilon_{t}$ is a $k \times 1$ column vector of residual returns of $r_{t}$, $k$ is the number of countries considered, $\mathrm{v}_{\mathrm{t}}$ is a $k \times 1$ column vector of standardized residual returns. $H_{t}$ is a $k \times k$ matrix of time-varying variances. Specifically,

$$
H_{t}=D_{t} R_{t} D_{t}
$$

where $R_{t}$ is a $k \times k$ matrix of time-varying correlations. $D_{t}$ is a $k \times k$ diagonal matrix of time-varying standard deviations of residual returns. The variances are obtained with univariate GARCH $(1,1)$ processes. Specifically, 


$$
h_{t}=b_{0}+b_{1} \varepsilon_{t-1}^{2}+b_{2} h_{t-1}^{2}
$$

In the third step, correlation coefficients are estimated. The correlation coefficients between stock index returns $i$ and $j$ at time $t$ are defined as:

\section{Discussion of results}

Table 1 represents the summary statistics of stock-index returns in the five African markets and the USA. As noted by empirical illustration, there was volatility in the stock returns in Africa between the periods of 2007

$$
\rho_{i j t}=\frac{E_{t-1}\left[\varepsilon_{i t} \varepsilon_{j t}\right]}{\sqrt{E_{t-1}\left[\varepsilon_{i t}^{2}\right] \sqrt{E_{t-1}\left[\varepsilon_{j t}^{2}\right]}}}=\frac{E_{t-1}\left[\sqrt{h_{i t} v i t} \sqrt{h_{j t} v_{j t}}\right]}{\sqrt{E_{t-1}\left[h_{i t} v_{i t}^{2}\right]} \sqrt{E_{t-1}\left[h_{j t} v_{j t}^{2}\right]}}=\frac{E_{t-1}\left[v_{i t} v_{j t}\right]}{\sqrt{E_{t-1}\left[v_{i t}^{2}\right]} \sqrt{E_{t-1}\left[v_{j t}^{2}\right]}}=E_{t-1}\left[v_{i t} v_{j t}\right]
$$

where $\quad \mathrm{E}_{t-1}\left[v_{i t}^{2}\right]=\mathrm{E}_{t-1}\left[h_{i t}^{-1} \varepsilon_{i t}^{2}\right]=h_{i t}^{-1} \mathrm{E}_{t-1}\left[\varepsilon_{i t}^{2}\right]=1$. Extending the analysis further to capture the correlation coefficients in different phases of the crisis, a dummy variable is introduced. The regression model is then given as:

$$
\rho_{i j, t}=\sum_{p=1}^{p} \phi_{p} \rho_{i j, t-p}+\sum_{k=1}^{3} \alpha_{k} D M_{k, t}+\ell_{i j, t}
$$

where is the pair-wise correlation coefficient between the stock returns of US and the stock returns of South Africa, Egypt, Nigeria, Tunisia and Kenya, such that $i=\mathrm{US}$ and $j=$ South Africa, Egypt, Nigeria, Tunisia and Kenya. Since our pre-tests using ARCH-LM statistics find significant heteroskedasticity in all cases, the conditional variance equation is assumed to follow a $\operatorname{GARCH}(1,1)$ specification including two dummy variables, $\mathrm{DMk}, \mathrm{t}(K=2,3)$ :

$$
h_{i j, t}=A_{0}+A_{1} h_{i j, t-1}+B_{1} \varepsilon_{i j, t-1}^{2}+\sum_{k=1}^{3} d_{k} D M_{k, t}
$$

The a priori expectation from the specified model above is as follows:

For the variance equation; $h_{t}=b_{0}+b_{1} \varepsilon_{t-1}^{2}+b_{2} h_{t-1}^{2}$, $b_{0}>0, b_{1}>0$ and $b_{2}>0$ to ensure positive variance and $b_{1}+b_{2}<1$ to ensure stationarity,

$$
\begin{aligned}
& \text { For the DCC } \quad(1,1) \quad \text { equation; } \\
& Q_{t}=\bar{Q}(1-\alpha-\beta)+\alpha v_{t-1} v_{t-1}^{l}+\beta Q_{t-1}
\end{aligned}
$$

Estimates $\alpha$ and $\beta$ (nonnegative scalars) are assumed to satisfy the stationary assumption. The model will be mean reverting as long as the non-negative scalars satisfy the constraint $\alpha+\beta<1$, implying that the volatility displays a persistent fashion. A significant alpha coefficient value in the DCC equation is an indication that correlations will vary appreciably over time (i.e. is a likelihood that evidence of contagion could be found). The beta parameter is an estimate of the persistence. If $\alpha+\beta=1$, the model will not be mean reverting, which would effectively mean the series would be integrated to order. and 2008. The data was however divided by breaking the entire sample into three periods (pre-crisis, crisis and post-crisis). When the first two moments for the three periods are compared, stock returns are generally higher during the pre-crisis period, than the crisis period which was all negative except for Tunisia. Variances are higher during the crisis period for all countries. Another thing to note is a high value of kurtosis during post crisis in Nigeria and Kenya. Also as expected, most of the index returns during the crisis period are negatively skewed. This suggests that, for these markets, big shocks are more

Table 1 Descriptive statistics on stock returns before the crisis, during the crisis and after the crisis. Source: Author's computation 2018

\begin{tabular}{lcclll}
\hline Stats & Mean & Variance & Skewness & Kurtosis & LB \\
\hline PRE-CRISIS & & & & & \\
USA & 0.689 & 3.924 & -0.370 & 2.258 & 13.672 \\
SOUTHA A & 2.544 & 18.621 & -0.073 & 2.054 & 15.762 \\
NIGERIA & 1.389 & 40.262 & 0.346 & 3.329 & 13.006 \\
EGYPYT & 5.034 & 112.049 & 0.504 & $4.179^{*}$ & 10.848 \\
TUNISIA & 2.047 & 10.631 & $0.795^{* *}$ & 2.869 & 16.605 \\
KENYA & 1.796 & 21.882 & -0.177 & $4.556^{* *}$ & 15.832 \\
CRISIS & & & & & \\
USA & -2.147 & 27.137 & $-0.995^{* *}$ & 3.785 & 8.503 \\
SOUTHA A & -0.605 & 28.659 & -0.148 & 2.928 & 8.941 \\
NIGERIA & -1.635 & 96.559 & $-1.175^{* * *}$ & 4.680 & $15.976^{*}$ \\
EGYPYT & -1.632 & 112.922 & $-1.130^{* *}$ & $4.262^{*}$ & 15.274 \\
TUNISIA & 0.706 & 13.752 & 0.041 & $4.716^{* *}$ & 5.946 \\
KENYA & -2.197 & 46.520 & -0.396 & 3.047 & 1.801 \\
POST-CRISIS & & & & & \\
USA & 1.367 & 16.636 & -0.379 & 3.463 & 33.681 \\
SOUTHA A & 1.324 & 12.947 & 0.067 & 2.827 & 49.300 \\
NIGERIA & 0.788 & 54.271 & $1.538^{* * *}$ & $10.060^{* * *}$ & 20.002 \\
EGYPYT & 1.436 & 76.939 & 0.214 & 3.486 & 30.918 \\
TUNISIA & 0.991 & 15.949 & $-0.545^{* *}$ & $4.582^{* *}$ & 24.294 \\
KENYA & 0.660 & 29.928 & $-0.734^{* * *}$ & $6.657^{* * *}$ & 43.581 \\
\hline Thetstastc & & & & & \\
\hline
\end{tabular}

The $t$ statistics are in parentheses. ${ }^{* * *},{ }^{* *}$, and ${ }^{*}$ denote statistical significance at the $1 \%, 5 \%$, and $10 \%$ levels, respectively. All variables are first differences of the natural log of stock indices times 100 


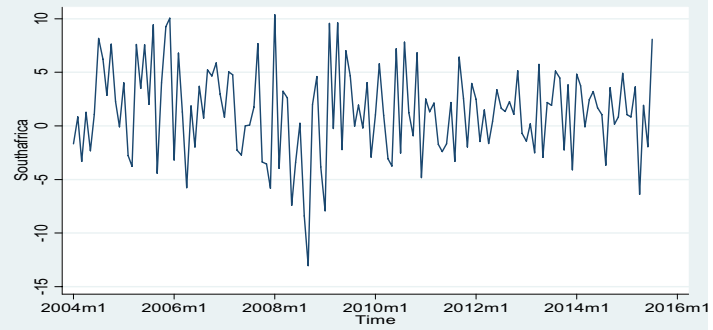

Fig. 1 South Africa Stock Returns

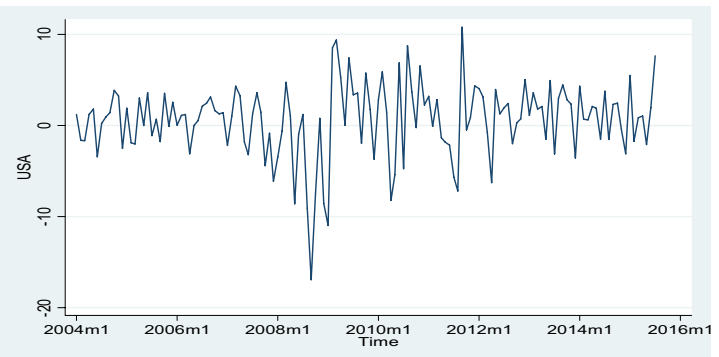

Fig. 2 US Stock Returns

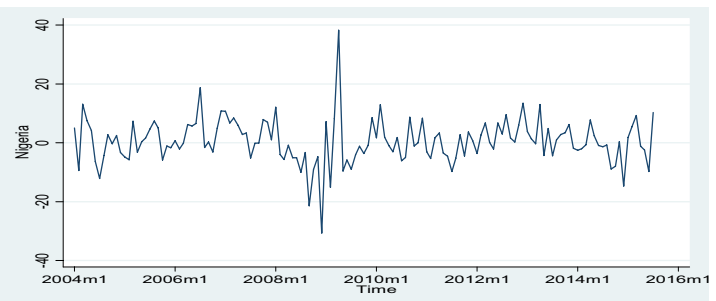

Fig. 3 Nigeria Stock Returns

likely to be present and that the stock-return series may not be normally distributed. Almost all of the stockreturn series are found not to have first-order autocorrelation except Nigeria, as suggested by the Ljung-box test statistics. The existence of this autocorrelation may result from trading of the stocks that make up the index.

\section{Relationship between stock returns in the African markets} and the US market (evidence of contagion)

For the purpose of this study, the specific objective is to examine the relationship between the returns of the specified African markets and the US markets during the 2007-2008 financial crises. To visualize the returns for each market, Figs. 1, 2, 3, 4, 5 and 6 are plotted to depict the series. From the diagram, it can be seen that US and African market returns were highly correlated

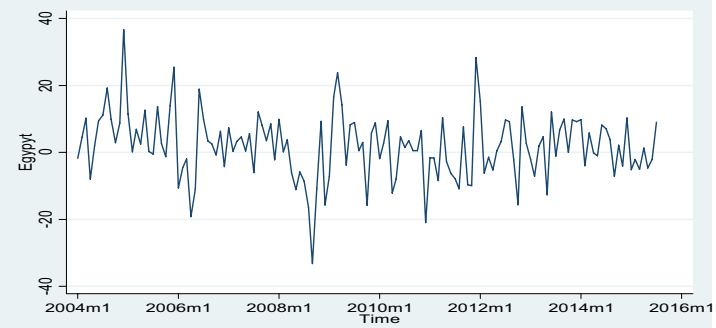

Fig. 4 Egypt Stock Returns

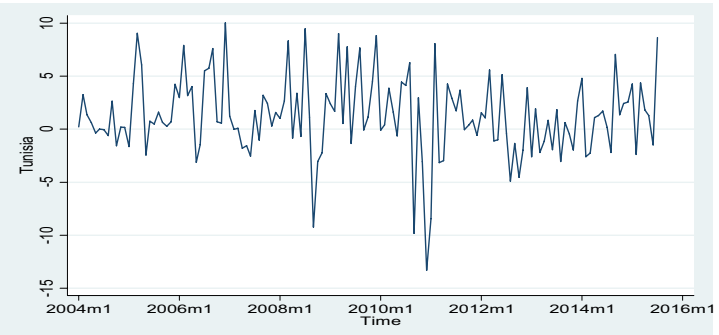

Fig. 5 Tunisia Stock Returns

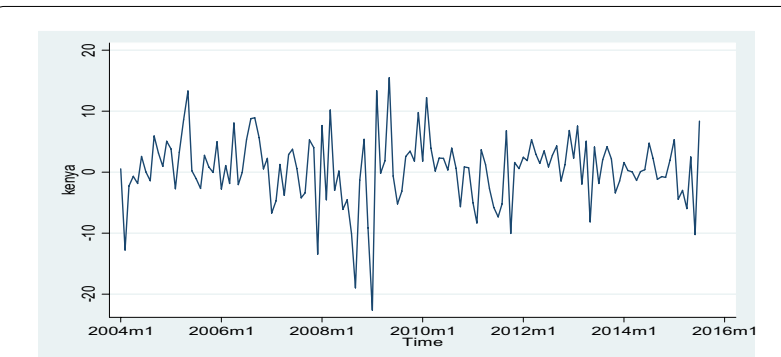

Fig. 6 Kenya Stock Returns

showing a sharp fall in the returns of all market in the early periods of 2008. This however indicates that the African countries were being affected by the shock that started from the US. Also, it can be seen that most of the African countries as well adjusted to this shock indicating a balance in stock returns as soon as the crisis ended. Hence, it can be said that the US market has a contagious effect on the African markets before, during and after the crisis period. This also can be addressed with the $\gamma_{2}$ effect in Table 2 in the mean equation showing significant effect on the African countries with South Africa and Nigeria being the largest. Also from the variance parameters $\alpha$ and $\beta$ showing the persistence level, the highest is 0.88 in South Africa and the lowest with 0.4 in kenya. 
Table 2 Estimation results from the DCC-GARCH model. Source: Author's computation, 2018

\begin{tabular}{|c|c|c|c|c|c|c|c|}
\hline & Return e & & & Variane & & & Persistence \\
\hline & $\gamma_{0}$ & $\gamma_{1}$ & $\gamma_{2}$ & C & A & B & \\
\hline SouthAfrica & $\begin{array}{l}1.639^{* * *} \\
(5.410)\end{array}$ & $\begin{array}{l}-0.235^{* *} \\
(-2.240)\end{array}$ & $\begin{array}{l}0.051 \\
(0.500)\end{array}$ & $\begin{array}{l}2.029 \\
(1.430)\end{array}$ & $\begin{array}{l}0.173^{* *} \\
(2.090)\end{array}$ & $\begin{array}{l}0.707^{* * *} \\
(5.440)\end{array}$ & 0.880 \\
\hline Nigeria & $\begin{array}{l}0.716 \\
(1.170)\end{array}$ & $\begin{array}{l}0.196^{*} \\
(1.940)\end{array}$ & $\begin{array}{l}0.209 \\
(1.260)\end{array}$ & $\begin{array}{l}7.661^{* *} \\
(2.100)\end{array}$ & $\begin{array}{l}0.177^{* *} \\
(2.210)\end{array}$ & $\begin{array}{l}0.690^{* * *} \\
(7.240)\end{array}$ & 0.866 \\
\hline Egypt & $\begin{array}{l}2.108^{* * *} \\
(2.720)\end{array}$ & $\begin{array}{l}0.093 \\
(0.950)\end{array}$ & $\begin{array}{l}0.063 \\
(0.310)\end{array}$ & $\begin{array}{l}30.329 \\
(0.780)\end{array}$ & $\begin{array}{l}0.065 \\
(0.710)\end{array}$ & $\begin{array}{l}0.603 \\
(1.250)\end{array}$ & 0.668 \\
\hline Tunisia & $\begin{array}{l}1.187^{* * *} \\
(3.680)\end{array}$ & $\begin{array}{l}0.101 \\
(1.090)\end{array}$ & $\begin{array}{l}0.029 \\
(0.330)\end{array}$ & $\begin{array}{l}3.994^{* *} \\
(2.060)\end{array}$ & $\begin{array}{l}0.191 \\
(1.520)\end{array}$ & $\begin{array}{l}0.538^{* * *} \\
(3.120)\end{array}$ & 0.730 \\
\hline Kenya & $\begin{array}{l}0.679 \\
(1.580)\end{array}$ & $\begin{array}{l}0.080 \\
(0.670)\end{array}$ & $\begin{array}{l}-0.006 \\
(-0.040)\end{array}$ & $\begin{array}{l}21.887 \\
(0.001)\end{array}$ & $\begin{array}{l}0.366 \\
(0.019)\end{array}$ & $\begin{array}{l}0.041 \\
(-0.785)\end{array}$ & 0.407 \\
\hline USA & $\begin{array}{l}0.856^{* * *} \\
(3.200)\end{array}$ & $\begin{array}{l}0.035 \\
(-0.360)\end{array}$ & & $\begin{array}{l}0.882 \\
(1.130)\end{array}$ & $\begin{array}{l}0.244^{* * *} \\
(2.590)\end{array}$ & $\begin{array}{l}0.718^{* * *} \\
(6.580)\end{array}$ & 0.962 \\
\hline
\end{tabular}

Table U.S. represents U.S. stock returns. The persistence level of the variance is calculated as the summation of the coefficients in the variance equations $(A+B)$. The $t$ statistics are in parentheses. ${ }^{* * *},{ }^{*}$, and ${ }^{*}$ denote statistical significance at the $1 \%, 5 \%$, and $10 \%$ levels with critical values of $2.58,1.96$, and 1.65 , respectively

Table 2 reports the estimates of the multivariate DCCGARCH model. The constant term in the mean equation is statistically significant for all the markets except Nigeria and Kenya. The AR(1) term in the mean equation $\left(\gamma_{1}\right)$ is significantly positive for Nigeria, while it is significantly negative for South Africa. However, $\operatorname{AR}(1)$ is not significant for Egypt, Tunisia and Kenya. The effect of U.S. stock returns $\left(\gamma_{2}\right)$ on Africa stock returns is, on average significant in South Africa and Nigeria. The coefficients for the lagged variance and shock-squared terms in the variance equation for Nigeria and South Africa is significant, which is consistent with time-varying volatility and justify the appropriateness of the GARCH $(1,1)$ specification. Note that the sum of the estimated coefficients in the variance equation $(a+b)$ is not close to unity for all the cases, implying that the volatility displays slow persistence.

\section{Statistical analysis of correlation coefficients in different phases of the crisis}

This section examines the time-series behavior of correlation coefficients and sort out the impacts of external shocks on their movements and variability. Using two dummy variables for different sub-samples allows us to investigate the dynamic feature of the correlation changes associated with different phases of crises. As the model implies, the significance of the estimated coefficients on the dummy variables indicates structural changes in mean or/and variance shifts of the correlation coefficients due to external shocks during the different phases of the crisis. The estimates using the maximum-likelihood method for the GARCH $(1,1)$ model are reported in Table 3.
The evidence shows that the $\mathrm{DM}_{2, t}$ in the mean equation is statistically significant for Nigeria and Egypt and not significant for South Africa, Tunisia and Kenya. This may possibly mean that the effect of the crisis on other countries has not been known. In the post-crisis period, the correlation coefficients, as shown in the estimates of $\mathrm{DM}_{3, t}$, decreased significantly in all cases where the stock markets might have been experiencing a shock based on the behavior of investors in response to the crisis. It is expected that when making fundamental decisions, investors would be more rational.

\section{Analysis of the vulnerability of financial contagion}

This is to investigate the vulnerability of financial contagion (increase in correlation) in the specified African markets before and after the episode of the 2007-2008 crisis. To address this, a null hypothesis is stated as:

$\mathbf{H}_{\mathbf{0}}$ There is no significant increase in correlations between the US and African markets during the 20072008 crisis.

From Table 4, the null hypothesis is rejected for Nigeria and South Africa and Kenya because an increase in correlation exist between the pre-crisis and crisis period, while we accept the null hypothesis for Egypt and Tunisia because there was no increase in correlations for the countries. This therefore summarizes that contagion was found in Nigeria, South Africa and Kenya.

\section{Analysis of vulnerability of herding (continuous correlation)}

This is to investigate the vulnerability of herding (continuous high correlation) in the specified African markets during and after the episode of the 2007-2008 crises. The hypothesis to be tested is stated as: 
Table 3 Test of changes in dynamic correlations between market stock returns during different phases of the crisis. Source: Authors computation 2018

\begin{tabular}{|c|c|c|c|c|c|}
\hline & South Africa & Nigeria & Egypt & Tunisia & Kenya \\
\hline \multicolumn{6}{|c|}{ Mean equation } \\
\hline Constant & $\begin{array}{l}2.08681 \\
(0.5713)\end{array}$ & $\begin{array}{l}0.77250 \\
(1.0428)\end{array}$ & $\begin{array}{l}4.362748^{*} \\
(1.5090)\end{array}$ & $\begin{array}{l}1.84230 \\
(0.5931)\end{array}$ & $\begin{array}{l}1.61047 \\
(0.7928)\end{array}$ \\
\hline$\rho_{t-1}$ & $\begin{array}{l}0.59577 \\
(0.0756)\end{array}$ & $\begin{array}{l}0.46649 \\
(0.1542)\end{array}$ & $\begin{array}{l}0.99086 \\
(0.2114)\end{array}$ & $\begin{array}{l}0.09585 \\
(0.0794)\end{array}$ & $\begin{array}{l}0.56332 \\
(0.1207)\end{array}$ \\
\hline$D M_{2, t}$ & $\begin{array}{l}-0.96209 \\
(0.9314)\end{array}$ & $\begin{array}{l}1.89505^{*} \\
(1.8657)\end{array}$ & $\begin{array}{l}-3.77196^{* *} \\
(2.3908)\end{array}$ & $\begin{array}{l}-0.86753 \\
(0.9871)\end{array}$ & $\begin{array}{l}-2.53542 \\
(1.4099)\end{array}$ \\
\hline$D M_{3, t}$ & $\begin{array}{l}-1.59334 \\
(0.6562)\end{array}$ & $\begin{array}{l}-0.53759 \\
(1.2752)\end{array}$ & $\begin{array}{l}-4.37373^{*} \\
(1.7917)\end{array}$ & $\begin{array}{l}0.86123 \\
(0.7384)\end{array}$ & $\begin{array}{l}-1.77603 \\
(0.9243)\end{array}$ \\
\hline \multicolumn{6}{|c|}{ Variance equation } \\
\hline Constant & $\begin{array}{l}1.37401 \\
(0.3099)\end{array}$ & $\begin{array}{l}1.26122 \\
(0.5388)\end{array}$ & $\begin{array}{l}1.38831 \\
(0.9809)\end{array}$ & $\begin{array}{l}1.28640 \\
(0.3034)\end{array}$ & $\begin{array}{l}0.86895 \\
(0.4392)\end{array}$ \\
\hline$\varepsilon_{t-1}^{2}$ & $\begin{array}{l}0.07411 \\
(0.1268)\end{array}$ & $\begin{array}{l}-0.043560 \\
(0.3597)\end{array}$ & $\begin{array}{l}0.61765 \\
(0.2655)\end{array}$ & $\begin{array}{l}0.21021 \\
(0.1325)\end{array}$ & $\begin{array}{l}0.10640 \\
(0.2409)\end{array}$ \\
\hline$h_{t-1}$ & $\begin{array}{l}0.75845 \\
(0.2379)\end{array}$ & $\begin{array}{l}0.83192 \\
(0.0734)\end{array}$ & $\begin{array}{l}-0.17014 \\
(0.0669)\end{array}$ & $\begin{array}{l}0.54463 \\
(0.1552)\end{array}$ & $\begin{array}{l}0.72677 \\
(0.2788)\end{array}$ \\
\hline$D M_{2, t}$ & $\begin{array}{l}0.72094 \\
(0.5295)\end{array}$ & $\begin{array}{l}-0.12459 \\
(0.6018)\end{array}$ & $\begin{array}{l}-0.27262 \\
(0.5983)\end{array}$ & $\begin{array}{l}0.35703 \\
(0.5567)\end{array}$ & $\begin{array}{l}1.33391 \\
(0.6577)\end{array}$ \\
\hline$D M_{3, t}$ & $\begin{array}{l}-0.61334 \\
(0.4363)\end{array}$ & $\begin{array}{l}-0.14626 \\
(0.2700)\end{array}$ & $\begin{array}{l}-0.24832 \\
(0.3020)\end{array}$ & $\begin{array}{l}0.22425 \\
(0.4342)\end{array}$ & $\begin{array}{l}-0.21671 \\
(0.5154)\end{array}$ \\
\hline$Q(5)$ & 1214.3954 & 1100.7270 & 2135.8967 & 1246.1406 & 1240.7504 \\
\hline $\mathrm{ARCH}(5)$ & 0.34044 & $0.47461^{*}$ & $1.26249 * * *$ & 0.32965 & $0.61658^{* *}$ \\
\hline
\end{tabular}

Table 4 Test of significant increases in correlation coefficients (USA as the source of contagion). Source: Authors computation, 2018

\begin{tabular}{lllllcc}
\hline & $\begin{array}{l}\text { Correlation } \\
\text { before crisis }\end{array}$ & $\begin{array}{l}\text { Correlation } \\
\text { during crisis }\end{array}$ & $\begin{array}{l}\text { Correlation } \\
\text { after crisis }\end{array}$ & $\begin{array}{l}\text { Adjusted correlation } \\
\text { after crisis }\end{array}$ & $\begin{array}{l}\text { Z-statistics } \\
\text { (unadjusted) }\end{array}$ & $\begin{array}{l}\text { Z-statistics } \\
\text { (adjusted) }\end{array}$ \\
\hline $\begin{array}{l}\text { USA as the source } \\
\text { USA-EGYPYT }\end{array}$ & 0.8803 & 0.5571 & 0.6910 & 0.6221 & $-3.012^{* * *}$ & $2.201^{* *}$ \\
USA-NIGERIA & 0.5581 & 0.5623 & 0.7893 & 0.7313 & $3.901^{* * *}$ & 0.231 \\
USA-SOUTHAFRICA & 0.8645 & 0.9684 & 0.9891 & 0.9129 & $2.109^{* *}$ & $1.901^{* *}$ \\
USA-TUNISIA & 0.9395 & -0.6568 & 0.5401 & 0.4901 & $3.830^{* * *}$ & $2.810^{* * *}$ \\
USA-KENYA & 0.5323 & 0.5784 & 0.6862 & 0.8351 & $2.520^{* * *}$ & $1.813^{* *}$ \\
\hline
\end{tabular}

The null hypothesis does not increase in correlation. The $z$-statistics are in parentheses. ${ }^{* * *}, * *$, and ${ }^{*}$ denote statistical significance at the $1 \%, 5 \%$, and $10 \%$ levels

$\mathbf{H}_{0}$ There is no continuous increase in correlations between the US and African markets after the 20072008 crisis.

From the result in Table 4, the null hypothesis is rejected for all the countries being examined. Having observed that there seems to be continuous increase in correlation for all the selected countries after the period of crisis, hence, it can be said that investment behavior dominates the latter part of the crisis. From empirical studies, it is evident that certain channels through which contagion takes place can be through investment behavior, or the openness of markets to take advantage of certain benefits to which integration and globalization possess.

\section{Summary of findings}

It is being said that though countries have opened up their financial markets to take advantage of global innovations, African markets still lag behind. The state of financial markets in Africa is usually characterized by their small size and the low liquidity. However, many studies consider that African markets are usually faced with little effect of contagion because of their low level 
of integration with the rest of the world as opposed to developed markets.

Hence from the findings of this paper, it can be said the African stock markets observed in this study were affected by the US stock returns, which clearly presents an evidence of financial contagion by these countries. Particularly, the Nigerian, South African and Kenyan stock markets are at higher risk because they were the most affected African countries by the US financial crisis, since they exhibited clear herding behavior to the US during the crisis and post crisis periods. These findings are in tandem with studies such as (see $[4,27])$ and quite contrary to $[6,26,32]$.

However, it is interesting to find out that Egypt which happens to be one of the largest stock market in Africa doesn't share in this risk, and this may be a pointer to the fact that the Egyptian stock market is the most independent and arguably developed financial market in Africa. However, a closer look at the financial market in Egypt shows that during the crisis period, it was also faced with its own internal market disturbances.

Investors in African stock markets should exercise extreme caution by observing the US stock market performance and returns before investing in their domestic stock markets since their markets are largely linked to and influenced by the US financial markets. Beyond this, Investors and fund managers in Nigeria, South Africa and Kenya are at a higher risk when investing in their stock markets because these two countries clearly exhibit herding behavior to the US stock market, indicating that similar decisions are taken by these stock markets.

\section{Conclusion}

This paper examines financial contagion in African market setting by way of investigating the impact of USA stock markets on stock markets in South Africa, Egypt, Kenya, Nigeria, and Tunisia, by employing monthly stock price data between 2004 and 2017. Result reveals that a significant relationship exists between the returns of the US market and the African markets and it is evident that the variances of financial returns increased dramatically. Inspection of the pre-crisis, crisis and post-crisis mean and variance estimation shows that the crisis period is characterized by substantial increases in volatility, establishing that the shock experienced in the US posed a threat to the African markets being examined.

While examining stock market contagion and the process of herding, the empirical findings support that the during the crisis period, Nigeria, South Africa and Kenya experienced a process of increased correlation indicating that contagion was found only in South Africa, Nigeria and Kenya while Egypt and Tunisia were not affected during the 2007-2008 financial crisis that sprang from the US. Also herding behavior was experienced in all the African markets with continuous increase in correlation after the crisis period.

\section{Competing interests}

The authors declare that they have no competing interests.

\section{Abbreviations}

AFDB: African Development Bank; FDI: Foreign direct investment; US: United States; UK: United Kingdom; CEA: Chinese economic area; MENA: Middle East and North Africa; CoVAR: Conditional value at risk; VAR: Vector autoregression; TSE: Tunisian stock exchange; KSE: Kenyan stock exchange; NSE: Nigerian stock exchange; JSE: Johannesburg stock exchange; EGX: Egyptian stock exchange; DCC: Dynamic conditional correlation; GARCH: Generalized autoregressive conditional heteroscedasticity; ARCH: Autoregressive conditional heteroscedasticity; LM: Langragian multiplier.

\section{Acknowledgements}

NIL.

\section{Author contributions}

Both authors contributed significantly to the writing of this paper. OMA wrote the introduction and the review of literature and ODO worked on the methodology, as well as the results and discussions. Both authors contributed in writing the conclusion and they both read and approved the final manuscript for submission.

\section{Funding}

The authors of this paper have no funding whatsoever for this research work.

\section{Availability of data and materials}

The dataset used in this study were majorly sourced by the authors from investing.com and are available on request.

\section{Author details}

${ }_{1}^{1}$ Department of Economics, Osun State University, Osogbo, Nigeria. ${ }^{2}$ Department of Economics, Obafemi Awolowo University, lle-lfe, Nigeria.

Received: 3 June 2020 Accepted: 29 January 2021

Published: 25 February 2021

\footnotetext{
References

1. African Development Bank (2009) Impact of the global financial crisis and economic crisis on Africa. Working Paper Series (9)

2. Arestis P, Caporale G, Cipollini A, Spagnolo N (2005) Testing for financial contagion between developed and emerging markets during the 1997 East Asian Crisis. Int J Fin Econ 10(4):359-367

3. Beirne J, Caporale G, Schulze-Ghattas M, Spagnolo N (2009) Volatility spillovers and contagion from mature to emerging stock markets. Deutsches Institut Für Wirtschaftsforschung, Discussion Paper (873)

4. Boako G, Alagidede P (2017) Evidence of shift-contagion in African stock markets: a CoVar-copula approach. Rev Dev Finance 7(2):142-156

5. Bouri El (2014) Isreali-Hezbollah war and global financial crisis in the Middle East and North African equity markets. J Econ Integr 29:1-19

6. Chen X, Hao A, Li Y (2020) The impact of financial contagion on the real economy. PLoS ONE 15(3):e0229913. https://doi.org/10.1371/journ al.pone.0229913

7. Cho J, Parhizgari A (2008) East Asian financial contagion under DCCGARCH. Int J Bank Finance 6(1):17-30

8. Chiang T, Jeon B, Li H (2007) Dynamic correlation analysis of financial contagion: evidence from Asian markets. J Int Money Finance 26:1206-1228

9. Claessens S, Forbes K (2004) International financial contagion: the theory, evidence and policy implications
} 
10. Claessens S, Dornbusch R, Park YC (2001) Contagion: why crises spread and how this can be stopped. In Stijn Claessens and Kristin Forbes 19-41

11. Collins D, Biekpe N (2003) Contagion: a fear for African equity markets? J Econ Bus 55:285-297

12. Corbet S, Twoney C (2015) European equity market contagion: an empirical application to Ireland's Sovereign debt crisis. Eur Financ Account J 10(3):15-34

13. Dornbusch R, Park CY, Claessens S (2000) Contagion: understanding how it spreads and how it can be stopped. World Bank Res Obs 15(2):177-197

14. Edwards S (2000) Contagion. . World Econ 23(7):873-900

15. Engle RF (2002) Dynamic conditional correlation: a simple class of multivariate generalized autoregressive conditional heteroscedasticity models. J Bus Econ Stat 20:339-350

16. Forbes K, Rigobon R (2002) No contagion, only interdependence: measuring stock market comovements. J Finance 57:2223-2261

17. Gallegati M (2012) A wavelet-based approach to test for financial market contagion. Comput Stat Data Anal 56(11):3491-3497

18. Hughes E, MacDonald M (2002) Stock volatility and contagion. MPRA Working Paper 12(3):110-126

19. Kaminsky G, Reinhart C (2000) On crises, contagion, and confusion. J Int Econ 51:145-168

20. Kaminsky G, Reinhart C, Vegh C (2003) The unholy trinity of financial contagion. J Econ Perspect 17(4):51-74

21. Kaminsky G, Reinhart C, Vegh (2010) Revisiting the trinity of financial contagion. J Econ Perspect 17(4):51-74

22. Karanasos M, Paraskevopoulos A, Ali F, Karoglou M, Yfanti S (2014) Modelling stock volatilities during financial crises: a time varying coefficient approach. J Empirical Finance 29:113-128

23. King M, Wadhwani S (1990) Transmission of volatility between stock markets. Rev Financ Stud 3:5-33
24. Masih A, Masih R (1997) Dynamic linkages and the propagation mechanism driving major international stock markets: an analysis of the preand post-crash eras. Q Rev Econ Finance 37(4):859-885

25. Missio S, Watzka S (2011) Financial contagion and the European debt crisis. CESifo working paper series No. 2554

26. Morales L, Andreosso-O'Callaghan B (2014) The global financial crisis: world market or regional contagion effects? Int Rev Econ Finance 29:108-131

27. Offiong A, Riman H, Godwin B (2018) Financial contagion and its impact on the Nigerian Stock Market. J Econ Bus 1(3):268-281

28. Rigobon R (2001) Contagion: how to measure it? Natl Bur Econ Res Work Pap 8118:289-334

29. Simone M, Alberto B, Danilo L (2019) Financial contagion and economic development: an epidemiological approach. J Econ Behav Organ 162:211-228

30. Sun Y, He JM (2012) Modelling contagious severity of the stock markets. Proceedings

31. Syllignakis NM, Kouretas PG (2011) Dynamic correlation analysis of financial contagion: evidence from the Central and Eastern European markets. Int Rev Econ Finance 20:717-732

32. Tiwari A, Mutascu M, Albulescu C (2016) Continuous wavelet transform and rolling correlation of European stock markets. Int Rev Econ Finance 42:237-256

33. Wang K, Thi T (2006) Does contagion effect exist between stock markets of Thailand and Chinese economic area (CEA) during the Asian flu? Asian J Manag Human Sci 1(1):16-36

34. World Bank (2013) A guide to the World Bank. The World Bank

\section{Submit your manuscript to a SpringerOpen ${ }^{\circ}$ journal and benefit from:}

- Convenient online submission

- Rigorous peer review

- Open access: articles freely available online

- High visibility within the field

- Retaining the copyright to your article

Submit your next manuscript at springeropen.com 